\title{
The Effect Promotion E-Commerce Toward Effectiveness Promotion By Using (AIDA) Methods
}

\author{
Nurvi Oktiani ${ }^{1}$, Kartika Yuliantari ${ }^{2}$, Taat Kuspriyono ${ }^{3}$, Haryani $^{4}$, Rani Kurniasari ${ }^{5}$ \\ $1,2,3,4,5$ Universitas Bina Sarana Informatika \\ Jl.Kramat Raya No.98, Senen, Jakarta Pusat 10450, Indonesia
}

e-mail: ${ }^{1}$ nurvi.nvk@bsi.ac.id, ${ }^{2}$ kartika.kkj@bsi.ac.id, ${ }^{3}$ taat.tat@bsi.ac.id, ${ }^{4}$ haryani.hyi@ bsi.ac.id,

${ }^{3}$ rani.rku@bsi.ac.id

\begin{abstract}
\begin{tabular}{lll}
\hline Informasi Artikel & Diterima: 01-11-2021 Direvisi: 18-11-2021 & Disetujui: 23-01-2022
\end{tabular}
Abstrak

Adpers -art Komunitas merupakan suatu komunitas yang dibangun atas dasar kesamaan hobi, yang mana hobi tersebut disalurkan melalui pembuatan karya seni dalam media kertas atau lainnya yang akan memebentuk 3(tiga)dimensi.Dalam penelitian ini menggunakan metode kuantitatif melalui Regresi linear berganda , sampel dalam penelitian ini terdiri atas 57 konsumen, dan analisis data menggunakan reliabilitas, validitas serta multikolinearitas, heterosedastisitas, autokorelasi, dan normalitas serta regresi, tujuan dari penelitian ini adalah untuk mengetahui pengaruh promosi melalui e-commerce terhadap efektifitas promosi dengan menggunakan metode AIDA bagi adpers - art komunitas, hasil yang didapatkan dalam penelitian ini dapat digambarkan model regresi sangat signifikan untuk mengukur variabel independent dan variabel dependen pada setiap $1 \%$ nya, koefisien regresi untuk attention sebesar 3.28, interest: 6.43, desire sebesar 3.324 yang dapat meningkatkan efektifitas promosi dan selebihnya action sebesar :3.309, saran untuk kedepannya bagi peningkatan adpers -art komunitas dimana perlu adanya peningkatan attention, desire, dan action konsumen dalam melakukam pembelian produk adpers-art komunitas, dan perlu adanya peningkatan strategi dalam meningkatkan efektifitas promosi
\end{abstract}

Kata Kunci: Promosi, E-Commerce, Efektifitas, AIDA

\begin{abstract}
Adpers-art communities is one of community have been built by similarity of hobbies, which is consist of making artworks in paper media or others which have three dimension. This research used quantitative method by multiply analysis regression, the sample from this research include 57 of consumer, the analysis data use reliability test, validity test, multicollinearity, Heteroscedasticity, Autocorrelation, normality, regression test. The Purpose of this research are known, the effect promotion E-Commerce toward effectiveness promotion by using AIDA Methods for Adpers - Art Community Product. For result, it can be described the regression model are significant for measuring percentage from dependent variable and change independent variable every $1 \%$, coefficient regression from attention :3.28, interest 6.43 , desire : 3.324 as much can make increase effectiveness promotion, and Action :3.309 as much give effect for increasing effectiveness promotion, in advice, Adpers Art Community must think of about how to improve attention, desire and action from consumer with any strategy for example increasing the effectiveness promotion by website and make specify strategies for improve especially attention, desire and action from consumer.
\end{abstract}

Keywords: Promotion, E- Commerce, Effectiveness, AIDA Methods

\section{Introduction}

Adpers - art communities is a community which have been built by similarity of hobbies, in despite of the adpers - art communities has many activities consist of making artworks in one of real media, especially the artworks can be pouring in visualization in paper media or others which have three dimension. Adpers - art communities is location in Tapos, Depok city, Indonesia have many vision and on creativity so that can be inspiration for many people. This communities have been produced among them project mural art, the statue of Indonesia culture, and papercraft or artworks come from papers which have been made by innovation and given added value for example pencil case, ashtray, flower vase, savings container, lantern 
lamps, hanging banner, beside that for papercraft product consist of Design Danbo single, Danbo Couple, Car design, Bus design, plane design, et all, Based on research and interview, sales for product from adpers-art communities sales consist of 2 until 5 million per month, from the sales we can give conclusion, the standard of sales is still low from the prediction, and for the case, the adpers-art community must think of the best solution for increasing the sales, because it is one of important thing to continue of survive for all activities of company therefore company must think of about marketing and how to increase the sales, because marketing is one of important factor for making value add to consumer based on the service which have been given to them, and Marketing process in adpers - art communities have been done through social media with the site : https://adpersart.blogspot.com, but if we want see the display of promotion, it can be given conclusion, promotion have been done in this site, it is not really effective for increasing the sales of adpers- art product, because the content of advertisement which can be bargained to consumer or stakeholder need more attention for innovating in the information field, one of steps for repairing or improving the advertisement need more innovation as make new private website, so that all of information which will be given to consumer will be clearly and consumer know more about the communities(Kuspriyono, Akil, \& Oktiani, 2019).

The organization structure from Adpers Art communities consist of Leader of community which have responsibility for coordinating all of community activities, vice leader of community whose have responsibility for controlling all of members and as a representative from leader, if the leader has a matter, Division of communities which involve visual art, communication who have tasks prepare all of subject to event and make communication with partner or client who want make partnership and collaboration, beside that the organization have secretary and treasurer and members, but in other hand in the reality adpers-art community have been facing many problem, one of them how to promote their product to consumer and how to give information with effectively to consumer, and how to make one of effectiveness Promotion used by strategically and it is not increase not only brand awareness but also how to encourage consumers to buy some product (Mittal \& Sethi, 2011), why promotion is important because promotion is the act of informing or reminding to consumer beside that persuade and remind customers about the company's objectives (Fransiska, Andhika, Indra, \& Rengganis, 2012), beside that promotion are essentially the flow of information or persuasion a person or organization to act that created the exchange marketing (Fransiska et al., 2012), the main purposes of the promotions are informing the market about the existence of a new product, a new way of usage of new product, communicate changes the market prices, explain how to use a product, inform service provide by the company, align the wrong impression, reduce the fears and concerns of buyers, persuading and establish a brand choice (Fransiska et al., 2012) about the specifications of the product and Effectiveness of Promotion demonstrated that there are important differences across categories, and beside of meaning effectiveness of promotion as a marketing management (Yusuf, 2012), promotion is effectiveness in promotion can make devalue of product image and beside that can increase effective in trial purchase of tool for facing it with AIDA Models is basic of marketing for advertisement in organizing based on customer perception (Ghirv, 2013), AIDA refers to attention, Interest, desire and action, usually this method have been used for marketing and advertising, this method can be increasing trust and attract the potential consumers attention and finally it will create purchasing process (Hadiyati, 2016) Based on the background of matter from the research that purpose is to knowing the comparison of advertisement by using manual or private website toward effectiveness promotion and how impact the private website toward effectiveness promotion by using AIDA (Attention, Interest, Desire and Actions) Method. The Aim for this research is looking for the effect Promotion by ecommerce toward Effectiveness promotion by AIDA Methods

The AIDA Model is an advertising for effecting model, and can describe all of Effect of advertising or media although for example sales force should be sustainably optimized on the basis of this model, the acronym AIDA Model stands for the term Attention, Interest, Desire, and Action.(Ganesh, 2020)

a. Attention : attract the attention of the visitor with appealing design and intuitive copy, accretive and belief, visualization of advertisement, message of advertisement

b. Interest : with increase the interest of consumer amount by strategically introducing benefit and advantage rather than focusing on self-appraise or do traditional marketing, interest indicator consist of easy for accessing, consumer perception, clearly messages

c. Desire : include create a desire for the goal that customer what it, beside that consist of to accomplish through well-knit information, product excellence, consumer desire, consumer curiosity

d. Action : an element that facilitate consumer to accomplish their task, and lead consumer to conversion tunnel, confidence for buying product, influence other consumer, brand Image product

AIDA Model is an formula which to plan a comprehensive advertisement and implemented for 
media selection, space size, and publication in media, which AIDA Model such as attention, interest, desire, and action is an populer hierarchy model for marketing and as guidance in marketing activity(Budiawan, Satria, \& Simanjuntak, 2017)

In another literature the concept of AIDA Model, can be controlled for successful implementation marketing strategies, this case concerating and developing for awarness of proposed product and help business to device marketing (Jiaqi, Teo, Tingting, \& Jiaxun, 2021)

In other side Effectiveness of promotion use for building brand sustainabilitybeside that The Effectiveness Promotion can be asa a strategic tool for marketing(Ahmed et al., 2019)

\section{Research Methodology}

Research used Quantitative method and for analysing data by multiply analysis regression, for the sample in this research consist of 57 people of the consumer, the data have been collected by questionnaire, it has been done the reliability, validity, multicollinearity, Heteroscedasticity, Autocorrelation, normality, regression test, toward four dimension which is consist of Attention, Interest, Desire and action (AIDA Models) for that determining for effecting Promoting by e- commerce toward effectiveness of Promotion, and the research use the multiply regression methods, for making conclusion from four dimensions (Attention, Interest, Desire and action), and from data analysis, we can know not only effect Promotion by ecommerce toward Effectiveness promotion by AIDA Methods but also we can know level from the four dimension in Adpers- art community, that whereas the effectiveness E-Commerce.

\section{Result and Discussion}

From the result of statistical analysis, we can describe it, in validity and Reliability.

\subsection{Reliability and Validity Result}

From the result of statistical analysis, we can describe it, in validity and Reliability

Table 1 : Reliability and Validity AIDA

\begin{tabular}{llll}
\hline Dimension & Indicator & Reliability & Validity \\
\hline Attention & Accretive and Belief & 0.861 & \\
& Visualization of & & 0,714 \\
& Advertisement & & 0,794 \\
& Message of & & 0.720 \\
Interest & Advertisement & & \\
& Easy for Accessing & & 0.680 \\
& Consumer Perception & & 0.679 \\
Desire & Clearly of Messages & & 0.671 \\
& Product excellence & & 0.326
\end{tabular}

$\begin{array}{ll}\text { Consumer Desire } & 0.480 \\ \text { Consumer curiosity } & 0.574\end{array}$

Action 0.701

$\begin{array}{ll}\text { Confidence For } & 0.633 \\ \begin{array}{l}\text { Buying Product } \\ \text { Influence other }\end{array} & 0.300 \\ \begin{array}{l}\text { Consumer } \\ \text { Brand Image Product }\end{array} & \\ & \end{array}$

Source: Statistical Package for the Social Sciences version 23

From the source we can describe, reliability from attention is 0,861 , interest: 0.820 , desire : 0.645 , and action : 0.701, and validity consist of Accretive and Belief: 0.714, Visualization of Advertisement : 0.794, Message of Advertisement : 0.720, Easy for Accessing, Consumer Perception, Clearly of Messages with amount : $0.671-0.680$, and Product excellence, Consumer Desire, Consumer curiosity with amount between 0, 326 0.574 and finally Confidence For Buying Product, Influence other Consumer and Brand Image Product between $0.300-0.633$

Table 2 : Reliability and Validity Effectiveness of

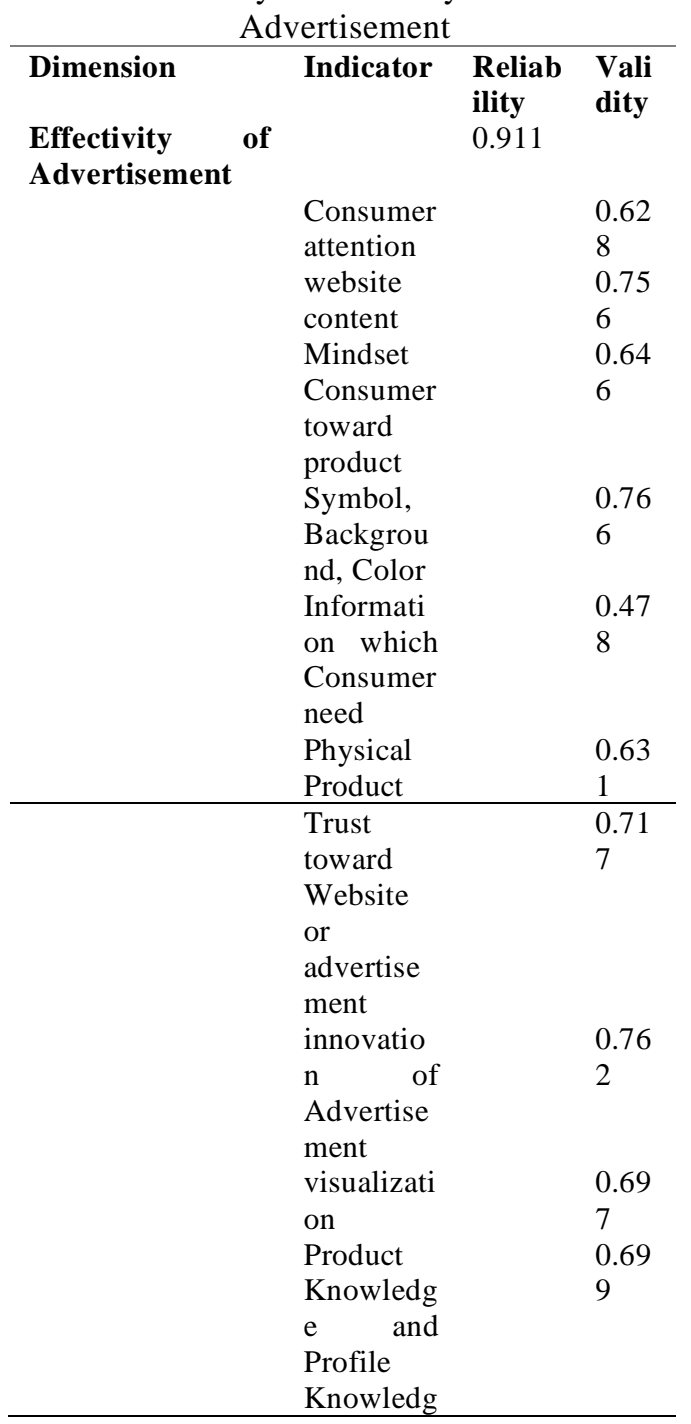


Source : Statistical Package for the Social Sciences version 23

From the source we can describe, reliability and validity of Effectiveness of Advertisement and all of indicator with validity with amount : $0.478-$ 0.762

\subsection{Multicollinearity detection with Correlation test} The meaning of Multicollinearity is linear relationship between independent variable in multiply regression, one of tool or multicollinearity detection, it can be used Correlation test

Table 3 : Correlation Correlations

\begin{tabular}{|c|c|c|c|c|c|}
\hline & & $\begin{array}{l}\text { X1(A } \\
\text { ttenti } \\
\text { on) }\end{array}$ & $\begin{array}{l}\text { X2(in } \\
\text { terest } \\
\text { ) }\end{array}$ & $\begin{array}{l}\text { X3(D } \\
\text { esire) }\end{array}$ & $\begin{array}{l}\text { X4 } \\
\text { (Act } \\
\text { ion) }\end{array}$ \\
\hline \multirow{4}{*}{$\begin{array}{l}\text { X1(Att } \\
\text { ention) }\end{array}$} & Pearson & 1 & $.696^{*}$ & $.652^{*}$ & .641 \\
\hline & $\begin{array}{l}\text { Correlati } \\
\text { on }\end{array}$ & & & & \\
\hline & $\begin{array}{l}\text { Sig. (2- } \\
\text { tailed) }\end{array}$ & & .000 & .000 & .000 \\
\hline & $\mathrm{N}$ & 57 & 57 & 57 & 57 \\
\hline \multirow{4}{*}{$\begin{array}{l}\text { X2(inte } \\
\text { rest) }\end{array}$} & Pearson & $.696^{*}$ & 1 & $.724^{*}$ & .559 \\
\hline & $\begin{array}{l}\text { Correlati } \\
\text { on }\end{array}$ & & & & *** \\
\hline & $\begin{array}{l}\text { Sig. (2- } \\
\text { tailed) }\end{array}$ & .000 & & .000 & .000 \\
\hline & $\mathrm{N}$ & 57 & 57 & 57 & 57 \\
\hline \multirow{4}{*}{$\begin{array}{l}\text { X3(Des } \\
\text { ire) }\end{array}$} & Pearson & $.652^{*}$ & $.724^{*}$ & 1 & .750 \\
\hline & $\begin{array}{l}\text { Correlati } \\
\text { on }\end{array}$ & $*$ & & & $* *$ \\
\hline & $\begin{array}{l}\text { Sig. (2- } \\
\text { tailed) }\end{array}$ & .000 & .000 & & .000 \\
\hline & $\mathrm{N}$ & 57 & 57 & 57 & 57 \\
\hline \multirow{4}{*}{$\begin{array}{l}\text { X4 } \\
\text { (Action } \\
\text { ) }\end{array}$} & Pearson & $.641^{*}$ & $.559^{*}$ & $.750^{*}$ & 1 \\
\hline & $\begin{array}{l}\text { Correlati } \\
\text { on }\end{array}$ & & & & \\
\hline & $\begin{array}{l}\text { Sig. (2- } \\
\text { tailed) }\end{array}$ & .000 & .000 & .000 & \\
\hline & $\mathrm{N}$ & 57 & 57 & 57 & 57 \\
\hline
\end{tabular}

\subsection{Heteroscedasticity Detection with Spearman Correlation}

Heteroscedasticity is mean variable of variant disturbance which is not constant, Heteroscedasticity appear at cross section data than time series, one of way for determining heteroscedasticity or not, it can be done by spearman correlation, in the spearman correlation, it can be described with comparison between $\mathrm{t}$ count and $\mathrm{t}$ critical,

Similarity $=\mathrm{T}_{\text {count }}: \underline{\text { correlation coefficient }(\sqrt{\mathrm{N}}-2)}$ $\sqrt{1-(\text { Correlation Coefficient })^{2}}$

$\mathrm{N}$ : Sample

Beside that $\mathrm{t}_{\text {critical }}$ with formula $: \alpha: 5 \%$, and $\mathrm{df}: \mathrm{N}-2$ (Ghozali, 2012)

\subsection{Heteroscedasticity Detection with Spearman}

\section{Correlation}

Heteroscedasticity is mean variable of variant disturbance which is not constant, Heteroscedasticity appear at cross section data than time series, one of way for determining heteroscedasticity or not, it can be done by spearman correlation, in the spearman correlation, it can be described with comparison between $t$ count and $t$ critical,

$T_{\text {count }}:$ correlation coefficient $(\sqrt{ } \mathrm{N}-2)$

$\sqrt{ } 1-{\text { Correlation Coefficient })^{2}}^{2}$

Beside that $\mathrm{t}$ critical with formula : $\alpha: 5 \%$, and $\mathrm{df}: \mathrm{N}-2$ (Ghozali, 2012)

From the Spearman Correlation Value, that can be calculated, $\mathrm{t}$ count for attention is (- 0.178) and $\mathrm{t}$ critical : 2,00 , interest variable $(-0.746)$, desire variable $(-0.544)$, and Action : (-0.663), compare between $t$ count and $t$ critical for determining Heteroscedasticity symptoms can be explained, if $\mathrm{t}$ count less than $\mathrm{t}$ critical so there is no heteroscedasticity but if $\mathrm{t}$ count more than $\mathrm{t}$ critical, the situation can be described, the result of regression has heteroscedasticity. From the data processing, it can be taken a conclusion, there is no heteroscedasticity symptoms

\subsection{Autocorrelation detection with Durbin - Watson}

The meaning of Autocorrelation is correlation between disruption variable with others, detection about autocorrelation can be used Durbin - Watson (DW) which one this method have been used by many researcher, in autocorrelation method with reduce critical value with lower limit $\left(\mathrm{d}_{1}\right)$ and Upper limit $\left(\mathrm{d}_{\mathrm{u}}\right) \mathrm{d}-$ count value can be described that there is no detection autocorrelation between negative autocorrelation or Positive autocorrelation, if Durbin Watson value (d) approach two (2) point so, it can be given a conclusion that there is no autocorrelation, this following a table which describe autocorrelation

Table 4 : Model Summary ${ }^{\mathrm{b}}$

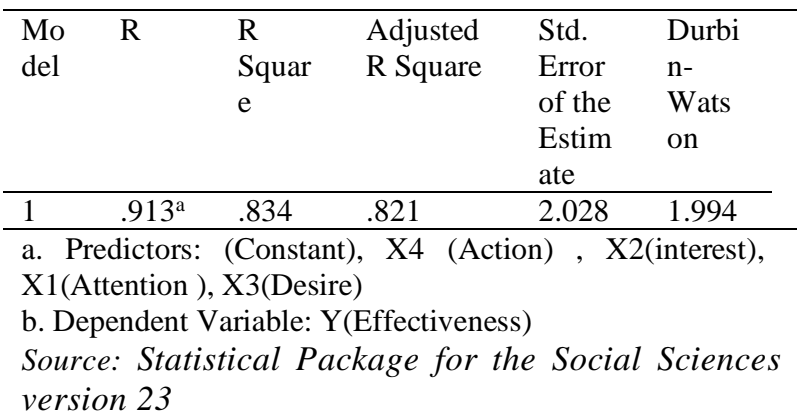

From above the table Model Summary

From the above of model summary, it can be explained that lower limit (dl) and upper limit(du) with the number of sample are 57 respondent and with 4 (four) variable consist of Attention, interest, desire, action and $\alpha: 5 \%$, each of value that $d_{1}: 1,444$ and $d_{u}: 1.727$ for Durbin Watson (d): 1,994, from the result, it can be described there is no autocorrelation because Durbin Watson value approach two (2) point, that is 1,994 for Durbin Watson

\subsection{Normality Test}

Assumption model for regression is residual for normal distribution, there is several method for determining 
normality distribution, there is consist of 1) Kosmorogov - Smirnov test, 2) Jarque - Bera (JB), for the research, kosmorogov - Smirnov test is a method for determining and knowing the samples, that come from specific population and distribution which called normal distribution(Ghozali, 2012)

The result of normal distribution can be taken from asymp.sig (2 tailed) and probabilities, where if probabilities value greater than from asymp.sig (2- tailed) (0.05), it can be taken conclusion we can receive alternative Hypothesis (H1) decision that the distribution is normal, but in despite of if probabilities value less from asymp.sig, it can be taken a conclusion we can receive for initial Hypothesis (H0) that the distribution is not normal (Ghozali, 2012)

Table 5 : One-Sample Kolmogorov-Smirnov Test

\begin{tabular}{|c|c|c|}
\hline & & $\begin{array}{l}\text { Unstandar } \\
\text { dized } \\
\text { Residual }\end{array}$ \\
\hline $\mathrm{N}$ & & 57 \\
\hline \multirow[t]{3}{*}{ Normal Parameters ${ }^{\mathrm{a}, \mathrm{b}}$} & Mean & .0000000 \\
\hline & Std. & 1.9543167 \\
\hline & $\begin{array}{l}\text { Deviatio } \\
n\end{array}$ & 7 \\
\hline \multirow{3}{*}{$\begin{array}{l}\text { Most } \\
\text { Differences }\end{array}$} & Absolute & .098 \\
\hline & Positive & .060 \\
\hline & Negative & -.098 \\
\hline \multicolumn{2}{|l|}{ Test Statistic } & .098 \\
\hline \multicolumn{2}{|l|}{ Asymp. Sig. (2-tailed) } & $.200^{\mathrm{c}, \mathrm{d}}$ \\
\hline \multicolumn{3}{|c|}{$\begin{array}{l}\text { a. Test distribution is Normal. } \\
\text { b. Calculated from data. } \\
\text { c. Lilliefors Significance Correction. }\end{array}$} \\
\hline
\end{tabular}

Source: Statistical Package for the Social Sciences version 23

From above the table which give one - sample Kolmogorov - Smirnov Test, can be described for asympt. Sig ( 2 tailed) with 0.200 , so that the value greater than probability $(0.05)$ so, it can be given conclusion for receiving alternative hypothesis which declared the population is normal or the distribution is normal.

\subsection{Regression Model}

The Formula For regression model is consist of Linear Function, and can be assumed in a form :

$\mathrm{Y}: \beta 0+\beta_{1} \mathrm{X}_{1}+\beta_{2} \mathrm{X}_{2}+\beta_{3} \mathrm{X}_{3}+\beta_{4} \mathrm{X}_{4}+\alpha_{\mathrm{i}}$

This Following table can be described the regression model for this case :

$$
Y: 3.460-0.180 X_{1}+0.297 X_{2}-0.136 X_{3}-0.151 X_{4}+\alpha_{i}
$$

from the regression model are elasticity for measuring percentage from dependent variable and change independent variable every $1 \%$, coefficient regression from attention is 3.28 and it is meaning for increasing $1 \%$ of attention can make amount 3.28 for effectiveness promotion, beside that every increasing amount for interest as much $1 \%$ can give coefficient regression from interest is 6.43 , and increasing independent variable for desire as much $1 \%$ can make effectiveness promotion as much 3.324 , finally increasing Action as much $1 \%$, it can be increased effectiveness promotion as much 3.309, from the previous research (Kuspriyono et al., 2019) promotion of the adpers-art community can be maximilied by promotion and supporting by goverment or related parties, but it not think of deep cleary explained, based on the result of research, it can be increased by AIDA Methods for Effectiveness ECommerce can be used by communities, By using AIDA Methods because it is concern the simple methods for knowing to what extent level of Effectiveness

\section{Conclusion}

From the result we can make conclusion:

The effect promotion E- Commerce toward effectiveness promotion by using AIDA Methods for Adpers - Art Community Product. For result, it can be described the regression model are elasticity for measuring percentage from dependent variable and change independent variable every $1 \%$, coefficient regression from attention :3.28, interest 6.43 , desire : 3.324 as much can make increase effectiveness promotion, and Action :3.309 as much give effect for increasing effectiveness promotion, in advice, Adpers Art Community, Adpers Art Community must plan a specify strategies for improving especially attention, desire, and action or Decision for buying a product from adpers - art Communities. In the future, for the other author who want or interest for continuing research about the effectiveness of E- Commerce, they can determine by other methods

\section{Reference}

Ahmed, R. R., Streimikiene, D., Berchtold, G., Vveinhardt, J., Channar, Z. A., \& Soomro, R. H. (2019). Effectiveness of Online Digital Media Advertising as A Strategic Tool for Building Brand Sustainability: Evidence from FMCGs and Services Sectors of Pakistan. Sustainability, $\quad$ 11(12), 3436. https://doi.org/10.3390/su11123436

Budiawan, R. D., Satria, A., \& Simanjuntak, M. (2017). The quasi experimental study of the influence of advertising creativity and exposure intensity toward buying action with aida approach. Independent Journal of Management \& Production, 8(2), 378. https://doi.org/10.14807/ijmp.v8i2.526

Fransiska, Y., Andhika, F., Indra, M., \& Rengganis, R. (2012). Determining the Most Effective Promotion Strategy for Clothing Company in Bandung, Indonesia. Procedia Economics and Finance, 4(Icsmed), 120-129. https://doi.org/10.1016/s2212-5671(12)003279

Ganesh, C. N. (2020). AIDA Model - A Panacea for Promoting Products. International Journal of Recent Technology and Engineering, 8(5), 1572-1576. https://doi.org/10.35940/ijrte.d7346.018520

Ghirv, A. I. (2013). the Aida Model for 
Advergames. USV Annals of Economics and Public Administration, 13(1(17)), 90-98.

Ghozali, I. (2012). Aplikasi Analisis Multivariate dengan Program IBM SPSS 20 Edisi 6. Semarang: Badan Penerbit Universitas Diponegoro.

Hadiyati, E. (2016). Study Of Marketing Mix And Aida Model To Purchasing On Line Product In Indonesia Ernani Hadiyati Economic and Business Faculty, Gajayana University, Malang, Indonesia. Journal, British Vol, Marketing Studies Centre, European Uk, Development, 4(7), 49-62.

Jiaqi, Y., Teo, B. S. X., Tingting, L., \& Jiaxun, Z. (2021). Influence of social media marketing in building relationship between brand loyalty of tourism products and products service quality. E3S Web of Conferences, 251. https://doi.org/10.1051/e3sconf/202125103006

Kuspriyono, T., Akil, I., \& Oktiani, N. (2019). Pendampingan Peningkatan Pemasaran Dan
Promosi Melalui E-Commerce Pada Adpers Art Community Kelurahan Sukatani Kecamatan Tapos Depok. J-ADIMAS (Jurnal Pengabdian Kepada Masyarakat), 7(1), 2227.

Mittal, M., \& Sethi, P. (2011). The effectiveness of sales promotion tools among indian consumers: An empirical study. Journal of Promotion Management, 17(2), 165-182. https://doi.org/10.1080/10496491.2011.58069 3

Yusuf, S. (2012). Assessing the Effectiveness of Promotion as a Marketing Department of Accounting And Finance. Journal of Emerging Trends in Economics and Management Sciences (JETEMS), 3(1), 1-6. 